\title{
How is Acculturation Linked to Subjective Wellbeing: Evidence from Turkish Immigrants in the United States
}

Kültürleşmenin Kişisel İyi Oluşla İlişkisi: Amerika Birleşik Devletleri’nde Yaşayan Türklerden Bulgular

Abdurrahim Güller ${ }^{1 *}$ (D), Murat Ylldırım²
${ }^{1}$ Agri Ibrahim Cecen University, Faculty of Science and Letters, Department of Sociology, Agri, Turkey
${ }^{2}$ Agri Ibrahim Cecen University, Faculty of Science and Letters, Department of Psychology, Agri, Turkey

\begin{abstract}
Today, international migration has caused many ethnic groups to live in culturally diverse societies. Turkish immigrants in the United States is one of those ethnic groups whose population is growing. Despite the growing Turkish population, there is currently little research on how acculturation can influence the subjective wellbeing of Turkish immigrants living in the United States. This study sought to examine to what extent heritage and host acculturations were associated with the subjective wellbeing of Turkish immigrants residing in the United States. The study included 306 foreign-born Turkish Americans who are between 19 to 69 years old $($ mean $=39.39)$. They completed the Vancouver Index of Acculturation, Satisfaction with Life Scale, and Short-Form of the Positive and Negative Affect Schedule. The results showed that participants reported higher levels of heritage and host acculturation, satisfaction with life and positive affect, and lower levels of negative affect. No gender differences were reported across these variables. Acculturation was positively related to satisfaction with life and positive affect and negatively related with negative affect. Host acculturation uniquely predicted satisfaction with life, positive affect, and negative affect after controlling for demographic characteristics. These findings highlight the unique importance of host acculturation in enhancing subjective wellbeing for Turkish immigrants and advance future research in this area.
\end{abstract}

Keywords: Acculturation, Satisfaction with life, Positive affect, Negative affect, Turkish immigrants.

\section{Öz}

Günümüzde uluslararası göç, birçok etnik grubun kültürel olarak farklı toplumlarda yaşamasına neden olmuştur. Amerika Birleşik Devletleri'ndeki yaşayan Türk göçmenler sayısı giderek artan bu etnik gruplardan birisidir. Artan Türk nüfusuna rağmen, kültürleşmenin Amerika Birleşik Devletleri'nde yaşayan Türk göçmenlerin kişisel iyi oluşlarını nasıl etkileyebileceğine dair pek az araştırma yapılmıştır. Bu çalışma, Amerika Birleşik Devletleri'nde ikamet eden Türk göçmenlerin kişisel iyi oluşları, miras kültürleri ile ev sahibi kültürün ne ölçüde ilişkili olduğunu incelemeyi amaçlamaktadır. Çalışmaya yaşları 19 ile 69 arasında değişen (ort. = 39.39) Amerikan vatandaşı 306 Türk dahil edilmiştir. Katılımcılar, Vancouver Kültürleşme İndeksi, Yaşam Doyumu Ölçeği, Pozitif ve Negatif Duygulanım Ölçeği Kısa Formu ve demografik özellikleri kapsayan anket formlarını tamamlamıştır. Araştırmanın sonuçlarına göre, katılımcıların daha yüksek düzeyde miras kültür ve ev sahibi kültüre katılım sağladıkları ve kültürleştikleri, yaşamlarından memnun ve olumlu duygulanım puanlarının yüksek olduğu ve daha düşük düzeyde de olumsuz duygulanım puanlarına sahip oldukları anlaşılmaktadır. Analiz sonuçlarına göre değişkenler arasında herhangi bir cinsiyet farkı bulunmamıştır. Bu çalışmada kültürleşme; yaşam doyumu ve olumlu duygulanımla olumlu olarak ilişkili iken olumsuz duygulanımla da olumsuz ilişkili olduğu bulunmuştur. Ev sahibi kültürü ile kültürleşme, demografik özellikleri kontrol ettikten sonra yaşamdan memnuniyet, olumlu ve olumsuz duygulanımı özgün bir şekilde açıklamaktadır. Bu bulgular, Türk göçmenler için kişisel iyi oluşu artırmada ve gelecekteki araştırmaları ilerletmede ev sahibi kültürü ile kültürleşmenin özgün önemini vurgulamaktadır.

Anahtar Kelimeler: Kültürleşme, Yaşam doyumu, Olumlu duygulanım, Olumsuz duygulanım, Türk göçmenler.

* Corresponding Author / Sorumlu Yazar: aguler@agri.edu.tr 


\section{Introduction}

Over the last few decades, the world has witnessed domestic and global immigrants more than ever before. In 2019, the number of international immigrants has reached almost 272 million (Population Division of the United Nations Department of Economic and Social Affairs, UN DESA, 2019). Over the past century, the path of these immigrants is continually to Western countries. The United States (US) is hosting more immigrants than any other Western country. By 2017, approximately 45 million people have immigrated to the US from various parts of the world (Migration Policy Institute, 2019; Pew Research Center, 2019).

Immigrants from all over the world have continued to immigrate to the US territory to start over a new life, seeking political protection, religious freedom, economic opportunity. More recently, the focus has been switched to the attainment of better education due to the notion that the US is an independent country (Alba, Reitz \& Simon, 2012). The process of immigrant integration in the US depends on the participation of immigrants in a social institution such as the educational system, labor market, social services as well as simultaneous social acceptance by host Americans (Alba et al., 2012). Although there is no integration policy of federal, state, or municipal, it can be inferred that the American public view and policy of the U.S. government about immigrants is laissez-faire that allows immigrants to survive in the US by using their resources (Bloemraad \& de Graauw, 2012).

\subsection{Turkish Immigrants in the US}

Immigration from the late Ottoman Empire and Turkey to the US was generally identified under three waves (Kaya, 2004). The first wave started in the 1800s and reached its peak in the early 1900s that contained mostly males and non-Turkish citizens of the Empire where their immigration motivations were largely political oppressions. After 1925, the US immigration law changed, and it imposed a national quota system that allotted to Turkey just 100 immigrants per year (Akgün, 2000). The second wave began in the early 1950s and 1980 when immigrants consisted of highly skilled workers, professionals, and accompanying families. In this period, Turkey's NATO membership, the Truman Doctrine, and the flexibilization of the US immigration laws in 1965 helped a significant boost to Turkish immigrants toward the US (Halman, 1980). The third wave has started in the 1980s till today and the motives and characteristics of immigrants take many forms including students, highly-skilled, and unskilled labor with diverse backgrounds.

As of today, the US Census Bureau (2018) reports a total of 216,700 Turkish Americans residing in the US. Of those, $73.37 \%$ are 18 years old and above and $51.6 \%$ are males. In terms of educational attainment for the population of 25 years and older, $33.1 \%$ have graduate or professional degrees, $25.7 \%$ have bachelor's degrees, $16 \%$ have some college or associate degree, $17.4 \%$ have high school diplomas, and $7.8 \%$ have lower degrees than high school diploma. Regarding their employment status, $66.4 \%$ of them are in the labor force while $2.7 \%$ of them are unemployed. Turks typically migrated to the US in the hopes of either having a better life standard or attaining good educational opportunities (Altschiller, 1995; Güler, 2016). Despite a high rate of Turkish immigrants residing in the US, there is a scarcity of evidence of how Turkish immigrants acculturate into the host culture and how their wellbeing is affected by the acculturation process. This study sought to provide evidence about the impact of acculturation on the wellbeing of this understudied population.

\subsection{Literature review}

Post-1965, immigrants to the US have been primarily non-European and non-White (Hernandez, Denton \& Macartney, 2007). While those immigrants make societies culturally diverse, they cause significant disruption in lifelong attachments (e.g., family, friends, and culture), immigration itself is often associated with different psychosocial problems due to the notion that immigrants lack the 
necessary skills needed (e.g., learning host language and culture, and getting involved in bureaucracies and civic entities) for them to manage new life in the new culture.

The process that immigrants go through when residing in a new and unfamiliar culture has become a topic of interest in the field of acculturation. People from distinct cultures living together due to immigration inevitably interact with each other in the host country which in turn may cause cultural and psychological changes. In this regard, Berry (1997) broadly defined acculturation as a multidimensional and dynamic process of cultural and psychological changes that result from ongoing contact between two distinct cultural groups. This contact can be direct or remote (Ferguson \& Bornstein, 2012) and can occur over long-time, across generations or centuries (Gezentsvey-Lamy, Ward \& Liu, 2013). The two most used theories explaining the acculturation process are assimilationist and bidimensional ones. Gordon (1964) referred acculturation as a process of assimilation during which immigrants acquire new host culture and they necessarily discard their heritage culture, which leads to the disappearance of it. This assimilationist theory requires a shift from the preservation heritage to the entire acquisition of host culture. On the other hand, Sommerlad and Berry (1970) spearheaded a bidimensional theory positing that the acculturation process may not be a zero-sum game. This process is a two-way process that changes can appear in either or both cultural groups and have a major impact on cultural patterns where heritage and host culture are presumably independent dimensions. In this context, individuals of heritage culture face two fundamental challenges: the extent to which they wish to preserve their heritage culture and the extent to which they wish to participate in the host society (Berry, Phinney, Sam \& Vedder, 2006). Four acculturation pathways emerge when these two challenges collide: integration, separation, assimilation, and marginalization (Berry, 2005; Berry \& Sabatier, 2010). Integration reflects a need to preserve key features of heritage culture along with interaction and involvement in the host society, requiring high interaction with each at the same time. Separation refers to a strong wish to preserve elements of the heritage whilst avoiding significant contact and involvement with members of the host society. Assimilation occurs when there is no wish to retain the heritage culture, but a strong intention to engage in or merge into the host society. Finally, marginalization takes place when there is little possibility of interest to maintain heritage culture, and interaction with the host community is simultaneously avoided at a high level.

Recent studies have indicated that acculturation is a multifaceted process in which immigrants may prefer multiple pathways regarding public and private aspects of their life. For example, they can prefer assimilation or integration in public and use separation in private life (Arends-Toth \& van De Vijver, 2007; Rania, Rebora, Migliorini \& Navas, 2019; Tip et al., 2015; Ünver \& Nicaise, 2019). The acculturation process is a complex phenomenon that members of host cultures can also play an important role in the involvement of immigrants into the host culture by either accepting or rejecting them. To elaborate Berry's model, Bourhis and his associates (1997) developed an interactive acculturation model. The model proposes an integrative approach that assesses the degree of fit between attitudes and behaviors of immigrants and members of the host culture. This process can either hinder or facilitate the adaptation of immigrants. According to this model, the acculturation process can be successfully achieved by cultural maintenance (willingness to maintain heritage culture) and cultural adaptation (desire for contact with others). When these two dimensions collide with one another, it can result in a combination of several relational outcomes: harmonious, problematic, or conflictual, depending on the agreement between immigrants, host society, and public policy (Bourhis, Moïse, Perreault, \& Senécal, 1997).

Szapocznik, Kurtines, and Fernandez (1980) proposed a bicultural model which has been advanced by Carlson and Güler (2018). The model hypothesizes both cultural involvement and cultural preference contain information from heritage and host cultures. Cultural involvement is based on the sum of 
heritage and host culture occupying a position at the two poles from total marginalization to total integration, whereas cultural preference rests on the difference between two cultures from separation to assimilation. Both cultural involvement and preference preserve a continuous scalar property that starts from heritage to host culture orientation, rather than choosing an arbitrary cut-point along these orthogonal vectors and dividing the plane into four discrete quadrants (Carlson \& Güler, 2018).

Acculturation is accepted as a psychological process in which it may not be smooth but problematic and closely linked to one's wellbeing such as stress, anxiety, depression, uncertainty, risk-taking, and perhaps family conflict. This process can provide great resources or undermine opportunities through discrimination and prejudice (Berry, 2019). Interactions with host culture are likely to improve one's wellbeing and help to overcome immigration-related psychosocial problems. Thus, to overcome these problems, immigrants are expected to adapt to and acquire host culture. Research has shown that the integration pathway is, with some few exceptions, the most desirable and strongly supported option while marginalization is the least favored by immigrants (Abu-Rayya \& Sam, 2017; Berry \& Hou, 2017; Güler, 2019) and assimilation and separation fall in between. Arguably, when people from different backgrounds interact with one another, they may not easily adapt to unfamiliar ways of life.

Subjective wellbeing is characterized as one's cognitive and affective evaluations of his or her life (Diener, Lucas \& Oshi, 2002). It comprises of two primary components: the emotional component (positive affect and negative affect) and the cognitive component (satisfaction with life). The emotional component refers to the presence of positive and absence of negative emotions and moods (e.g., happy, sad, or fatigued) which individuals experience in their daily life (Barsade \& Gibson, 2007). The cognitive component, on the other hand, represents an assessment of how well one's life going in general. Individuals who have high subjective wellbeing report higher levels of satisfaction with life and positive affect and lower levels of negative affect (Diener, 1984). Different factors were found to be related with subjective wellbeing including but not limited to personality (Yildirim \& Belen, 2018), health (Diener, Pressman, Hunter \& Delgadillo-Chase, 2017), psychosocial functioning (Nikolaev, Boudreaux \& Wood, 2019), and demographic characteristics (Lucas \& Diener, 2015).

Studies examining the association between acculturation and wellbeing have yielded inconsistent findings. Several studies (Berry \& Hou, 2016; Berry \& Sabatier, 2010; Dimitrova, Bender, Chasiotis \& van de Vijver, 2013; Hashemi, Marzban, Sebar \& Harris, 2019; van Oudenhoven \& Benet-Martinez, 2015) reinforced the idea that when immigrants engage in both heritage and host cultures, endorsing the integration, they reported the highest levels of wellbeing. Meta-analysis studies of Jetten et al. (2015) and Nguyen and Benet-Martinez (2013) indicated that integration is linked to better wellbeing, whereas marginalization is linked to poor wellbeing. However, other studies indicate that preferring one of the acculturation paths may not improve but it can hinder wellbeing (Obasi \& Leong, 2009; Shin \& Lach, 2014). Considering these inconsistent findings, the association between acculturation and wellbeing thus requires further investigation.

Previous studies have also identified other factors that influence the acculturation process and the wellbeing of immigrants. The demographic variables such as gender, age, and length of residence in the host country are among the factors that have an impact on the acculturation process (Nguyen \& Benet-Martinez, 2013). Gender differences seem to be the most emerging factor in the acculturation and wellbeing of immigrants. Early research indicated that women, compared to men, are more likely to keep their heritage culture and less likely to engage in host culture (Amer \& Hovey, 2007; Sam, Vedder, Ward, \& Horenczyk, 2006). By contrast, Balidemaj and Small (2018) found that Albanian women in the US are acculturated more to host culture than their counterparts and have greater wellbeing with a longer stay. Similarly, women were found to have greater life satisfaction than men (Berry \& Hou, 2016). Age is another important factor affecting acculturation, as those who migrate at 
a younger age acculturated more to host culture (Khawaja, Yang, \& Cockshaw, 2016). People of different ages are likely to go through different life transitions when they immigrate to another country and this experience has differential effects on their wellbeing. Rudner and Orpana (2012) found that younger immigrants reported greater wellbeing. Length of residence in the host country is one of the main emerging predictors, moderators, and mediators of how immigrants acculturate and how well they adapt. Some of the previous studies suggest that those, who reside longer in the host society, are more acculturated to host culture (Grigoryev \& Berry, 2017; Schwartz, Unger, Zamboanga, \& Szapocznik, 2010). Some research found that longer residence in the host country is related with lower wellbeing of immigrants (Berry \& Hou, 2016; Gunasekara, Grant, \& Rajendran, 2019; Kwak, 2018) while others reported a positive relationship between the length of stay in the host society and wellbeing, especially for women (Balidemaj \& Small, 2018).

\subsection{Present Study}

The literature has examined the various ways in which immigrants engage with both hosting and heritage cultures, and the relationship between the engagement and wellbeing but it has not given definite answers to the question like how acculturation and subjective wellbeing are related with one another nor has it indicated if they can be explained by third variables such as demographic variables. Despite a wealth of literature on the relationship between acculturation and the wellbeing of immigrant groups in Europe and North America, there is scant research evidence on the relationship between acculturation and wellbeing among Turkish immigrants in the US while the Turkish population significantly increases. Thus, the purpose of the current study was to examine the relationship between acculturation and subjective wellbeing among Turkish immigrants in the US. In the light of existing literature, we expected that heritage and host acculturations would share significant positive correlations with satisfaction with life and positive affect and a significant negative correlation with negative affect. We also expected heritage and host acculturations would significantly predict all aspects of subjective wellbeing after controlling for the contribution of sociodemographic variables.

\section{Method}

\subsection{Participants}

Participants consisted of 306 foreign-born Turkish American adult immigrants residing in the US between 19 to 69 years old (mean $=39.39 \pm 10.60)$. Out of the 306 participants, $169(55.2 \%)$ were male and 137 (44.8\%) were female. The length of stay in the US varied from 1 year to 49 years, with a mean of $14.13(\mathrm{SD}=11.08)$. Regarding participants' educational attainment, $11.1 \%$ of participants had a high school diploma or less education, $8.8 \%$ had associate/vocational degree, $31 \%$ had a bachelor's degree, $32.4 \%$ had a master's degree, and $16.7 \%$ had a doctoral or professional degree. One hundred fortyseven (48\%) of participants, in terms of legal status, had US citizenship and 70 (22.9\%) were holding a green card, 62 (20.3\%) had only a work permit, and the remaining were diplomats, tourists, refugees, etc. Regarding marital status, $25.2 \%$ reported being single/never married, 59.8\% reported being married, and 15\% reported being divorced/separated/widowed (see Table 1).

\subsection{Measures}

Acculturation: Acculturation was measured using the Vancouver Index of Acculturation (VIA) which assesses heritage and host culture (Ryder, Alden, \& Paulhus, 2000). The VIA is advantageous in terms of being a highly reliable and valid bidimensional measure and feasible to all ethnic groups as an instrument of acculturation. The scale comprises 24 items measuring several aspects of acculturation such as social relationships, values, entertainment, marriage, food preference, and adherence to tradition. The VIA has two subscales with 12 items per subscale: heritage acculturation and host acculturation. Items were rated on a 9-point Likert-type scale varying from 1 (strongly disagree) to 9 
(strongly agree). Sample items are "I enjoy social activities with Turkish people" (involvement with heritage culture) and "I enjoy social activities with American people" (dominant American host culture). An overall mean was calculated for each scale, with higher scores indicating a higher orientation toward each culture. Internal consistencies for the orientation towards heritage culture and the dominant American host culture subscales were respectively 0.89 and 0.87 in this study.

Table 1

Frequency Statistics

\begin{tabular}{lcc}
\hline \multicolumn{1}{c}{ Variable } & Frequency & Percent \\
\hline Gender & & \\
$\quad$ Male & 258 & 55.25 \\
$\quad$ Female & 209 & 44.75 \\
Socioeconomic status & & \\
$\quad$ Low & 208 & 44.54 \\
$\quad$ Middle & 167 & 35.76 \\
$\quad$ High & 92 & 19.70 \\
Legal status in the USA & & \\
$\quad$ U.S. citizen & 165 & 35.33 \\
Permanent resident/ have a green card & 78 & 16.70 \\
Not U.S. citizen/have a work permit & 101 & 21.63 \\
Other (e.g., diplomats, visitors) & 123 & 26.34 \\
Acculturation pathways & & \\
Separation & 45 & 14.71 \\
Integration & 172 & 56.21 \\
Assimilation & 56 & 18.31 \\
Marginalization & 33 & 10.78 \\
\hline
\end{tabular}

Satisfaction with Life: Life satisfaction was assessed by the Satisfaction with Life Scale (SWLS; Diener, Emmons, Larsen, \& Griffin 1985) that comprises 5 items assessing global life satisfaction. Items were answered using a 9-point Likert-type scale ranging from 1 (completely disagree) to 9 (completely agree). The sample item is "The conditions in my life are excellent" Internal consistency for the scale was 0.88 in this study.

Positive and Negative Affect: Emotions or mood states were measured with a short form of Positive and Negative Affect Schedule (PANAS). The PANAS was a self-report scale originally developed by Watson, Clark, and Tellegen (1988) to assess positive affect (PA) and negative affect (NA). The short form of PANAS (Thompson, 2007) used in the present study consists of 10 -items, 5 items for PA (e.g., inspired and alert), and 5 items for NA (e.g., afraid and upset). Participants answered each item using a 5-point Likert scale format ranging from 1 (very slightly) to 5 (very much). In this study, internal consistencies for PA and NA subscales were respectively reported as 0.86 and 0.89 .

\subsection{Procedure}

Surveys were distributed using a snowball sampling approach through Turkish cultural associations and institutions in the US. The target participants were asked to distribute the battery of questionnaires with acquaintances. To maximize demographic diversity, we aimed to reach as many participants as possible 
from different socioeconomic backgrounds who met the criteria of being Turkish, with a minimum age of 18 years old, and living in the US. The package of the questionnaires was administered using a paperpencil or online format both in Turkish and English languages to minimize language barriers and increase the response rate. A written or online informed consent was obtained at the beginning of the survey. All participants were informed that participation in the study was voluntary, their responses would be anonymous, and no personal identifying information would be disclosed. Measures originally written in English were translated into Turkish using the traditional forward-backward translation technique. With online design, participants were sent an email with a description of the study and a web link to the survey. Participants were not compensated for their involvement.

\subsection{Data analysis}

Descriptive statistics were computed to understand participants' characteristics. An independent sample t-test was conducted to compare the gender across the study variables. Pearson correlation was used to explore the relationship between demographic variables, acculturation, and subjective wellbeing. Regression analysis was used to examine whether acculturation can function as a predictor of subjective wellbeing. All data were analyzed using IBM SPSS 24.0 for Windows.

\section{Results}

Descriptive statistics for scales used in this study and information concerning the distribution of the scales are presented in Table 2. Participants reported higher scores on the scales of heritage, host acculturation, and satisfaction with life and lower scores on the scales of positive affect and negative affect. Furthermore, skewness and kurtosis statistics for each of the variables displayed in Table 2 were no larger than 0.74 and 0.68 , respectively. Thus, they did not contravene the recommended threshold values for these two statistics that range between $+/-1$, suggesting a "very good" range of symmetry of a normal univariate distribution (West, Finch, \& Curran, 1995).

Table 2

Descriptive Statistics of Scales Used in the Present Study

\begin{tabular}{|c|c|c|c|c|c|c|c|c|}
\hline \multirow{2}{*}{ Variable } & \multirow{2}{*}{ Min } & \multirow{2}{*}{ Max } & \multirow{2}{*}{ Mean } & \multirow{2}{*}{$\mathrm{SD}$} & \multicolumn{2}{|c|}{ Skewness } & \multicolumn{2}{|c|}{ Kurtosis } \\
\hline & & & & & Statistic & SEM & Statistic & SEM \\
\hline Heritage acculturation & 2 & 9 & 7.12 & 1.32 & -0.71 & 0.14 & 0.24 & 0.28 \\
\hline Host acculturation & 3 & 9 & 6.34 & 1.28 & -0.32 & 0.14 & -0.23 & 0.28 \\
\hline Satisfaction with life & 7 & 45 & 30.54 & 8.17 & -0.61 & 0.14 & -0.04 & 0.28 \\
\hline Positive affect & 5 & 25 & 19.01 & 3.46 & -0.68 & 0.14 & 0.64 & 0.28 \\
\hline Negative affect & 5 & 25 & 10.79 & 3.93 & 0.74 & 0.14 & 0.68 & 0.28 \\
\hline
\end{tabular}

An independent sample $t$-test was performed to compare men and women across the study variables. The results are presented in Table 3 . There were no statistically significant differences between men and women for all study variables $(p>0.05)$.

Pearson product-moment correlation coefficients were calculated among demographic information, heritage acculturation, host acculturation, and subjective wellbeing dimensions. The results are reported in Table 4. The higher level of heritage was related with higher levels of host acculturation, satisfaction with life, and positive affect, and lower levels of negative affect. Higher host acculturation was related with greater satisfaction with life and positive affect and lesser negative affect. Age, socioeconomic status in the US, length of stay in the US, and degree of having legal status in the US were positively correlated with host acculturation, satisfaction with life, and positive affect whereas they were negatively correlated with negative affect. 
Table 3

Comparison of Men and Women for the Study Variables

\begin{tabular}{lcccccc}
\hline \multicolumn{1}{c}{ Variable } & Gender & $\mathrm{N}$ & Mean & SD & $t$ & $p$ \\
\hline \multirow{2}{*}{ Heritage acculturation } & Male & 169 & 7.04 & 1.34 & \multirow{2}{*}{0.28} \\
& Female & 137 & 7.21 & 1.29 & & \\
Host acculturation & Male & 169 & 6.32 & 1.24 & -0.36 & 0.72 \\
& Female & 137 & 6.37 & 1.33 & & 0.66 \\
Satisfaction with life & Male & 169 & 30.72 & 7.87 & 0.44 & \\
Positive affect & Female & 137 & 30.31 & 8.54 & & 0.57 \\
& Male & 169 & 18.91 & 3.49 & -0.57 & \\
Negative affect & Female & 137 & 19.14 & 3.42 & & 0.19 \\
& Male & 169 & 10.53 & 4.13 & & -1.31 \\
\hline
\end{tabular}

Relevant assumptions of hierarchical regression analysis were tested before conducting the analysis. G*Power (Erdfelder, Faul \& Buchner, 1996) was utilized to determine the minimum required sample size for multiple regression analysis, given the desired probability level of $p<0.05$, the number of predictors in the model being 7 , anticipated effect size being medium $\left(f^{2}=0.15\right)$, and the desired statistical power level of 0.95 . The analysis produced the minimum required sample size as $n=74$ suggesting that the sample size of $n=306$ recruited for this analysis was high above the minimum sample size. Concerning multicollinearity among the predictors, the variance inflation factor (VIF) and tolerance for each of the single predictor variables were respectively no greater than 2.76 and no smaller than 0.36 . Thus, they did not violate the assumption of multicollinearity considering that the threshold values for VIF of at least 5 and tolerance statistics of less than 0.2 are indicative of collinearity between predictors (Cheung \& Rensvold, 2002). As shown above, no major problems regarding normality were observed.

Three hierarchical multiple regression analyses were conducted to further assess the relationship between heritage acculturation, host acculturation, and subjective wellbeing dimensions. In each regression analysis, one subjective wellbeing dimension (i.e. satisfaction with life, positive affect, negative affect) was entered as the dependent variable, and heritage and host acculturations were entered as potential independent variables in Step 2 while demographic information such as age and gender were controlled in Step 1. A summary of the results of the regression analyses is presented in Table 5. The results of the first regression analysis indicated that $9 \%$ of the total variance in satisfaction with life was explained by the demographic information in Step 1, with socioeconomic status $(\mathrm{B}=2.15, p<$ .001) being a significant predictor. The inclusion of heritage and host acculturation into Step 2 led to a significant contribution to the model by explaining an additional $5 \%$ of the variance in satisfaction with life with the significant positive predictor of host acculturation $(\mathrm{B}=1.20, p<.001)$. The results of the second regression analysis showed that $14 \%$ of the total variance in positive affect was explained by the demographic information in Step 1, socioeconomic status in the US $(B=0.64, p<.05)$ and legal status in the US $(\mathrm{B}=1.02, p<.001)$ being a significant predictor. In Step 2, host acculturation $(\mathrm{B}=$ $0.38, p<.05$ ) was found to be a significant predictor by accounting for an additional $3 \%$ of the variance in positive affect. Finally, results of the third regression analysis demonstrated that $13 \%$ of the total variance in negative affect was explained by the demographic information in Step 1, with socioeconomic status in the US $(\mathrm{B}=-0.97, \mathrm{p}<.001)$ and legal status in the US $(\mathrm{B}=-1.06, p<.001)$ being significant predictors. When heritage and host acculturation were entered into Step 2, the model 
produced significant results by explaining an additional $3 \%$ of the variance in negative affect with host acculturation $(\mathrm{B}=-0.50, p<.001)$ being the only significant predictor.

\section{Table 4}

Correlations Between Primary Study Variables

\begin{tabular}{|c|c|c|c|c|c|c|c|c|c|c|}
\hline Variable & 1 & 2 & 3 & 4 & 5 & 6 & 7 & 8 & 9 & 10 \\
\hline 1. Gender & 1 & & & & & & & & & \\
\hline 2. Age & .07 & 1 & & & & & & & & \\
\hline 3. Socioeconomic status in the US & $-.27^{* *}$ & $.13^{*}$ & 1 & & & & & & & \\
\hline 4. Length of stay in the US & .04 & $.74^{* *}$ & $.24^{* *}$ & 1 & & & & & & \\
\hline 5. Legal status in the US & -.02 & $-.47^{* *}$ & $-.22^{* *}$ & $-.57^{* *}$ & 1 & & & & & \\
\hline 6. Heritage acculturation & .06 & .01 & .04 & .10 & -.06 & 1 & & & & \\
\hline 7. Host acculturation & .02 & $.27^{* *}$ & $.19^{* *}$ & $.36^{* *}$ & $.31^{* *}$ & $.22^{* *}$ & 1 & & & \\
\hline 8. Satisfaction with life & -.03 & $.15^{* *}$ & $.24^{* *}$ & $.22^{* *}$ & $.19^{* *}$ & $.17^{* *}$ & $.28^{* *}$ & 1 & & \\
\hline 9. Positive affect & .03 & $.18^{* *}$ & $.20^{* *}$ & $.24^{* * *}$ & $.35^{* *}$ & $.13^{*}$ & $.26^{* * *}$ & $.57^{* *}$ & 1 & \\
\hline 10. Negative affect & .08 & $-.16^{* *}$ & $-.24^{* *}$ & $-.17^{* *}$ & $-.30^{* *}$ & $-.12^{*}$ & $-.26^{* *}$ & $-.53^{* *}$ & $-.71^{* *}$ & 1 \\
\hline
\end{tabular}

$* * p<.01 . * p<.05$

Table 5

Summary of Hierarchical Regression Analysis for Variables Predicting Subjective Wellbeing

\begin{tabular}{|c|c|c|c|c|c|c|c|c|c|c|c|c|}
\hline \multirow[b]{2}{*}{ Variable } & \multicolumn{4}{|c|}{ Satisfaction with life } & \multicolumn{4}{|c|}{ Positive affect } & \multicolumn{4}{|c|}{ Negative affect } \\
\hline & B & Beta & $\mathrm{t}$ & Sig & B & Beta & $\mathrm{t}$ & Sig & B & Beta & $\mathrm{t}$ & $\mathrm{Sig}$ \\
\hline Step 1 & \multicolumn{4}{|c|}{$\begin{array}{l}F(5,305)=5.85, r=.30 \\
r^{2}=.09, p<0.01\end{array}$} & \multicolumn{4}{|c|}{$\begin{array}{l}F(5,305)=9.78, r=.37 \\
r^{2}=.14, p<0.01\end{array}$} & \multicolumn{4}{|c|}{$\begin{array}{l}F(5,305)=8.70, r=.36 \\
r^{2}=.13, p<0.01\end{array}$} \\
\hline Gender & 0.35 & 0.02 & 0.37 & 0.71 & 0.44 & 0.06 & 1.12 & 0.26 & 0.26 & 0.03 & 0.59 & 0.56 \\
\hline Age & -0.01 & -0.02 & -0.23 & 0.82 & 0.00 & 0.00 & -0.05 & 0.96 & -0.03 & -0.08 & -0.97 & 0.33 \\
\hline SES in US & 2.15 & 0.20 & 3.31 & 0.00 & 0.64 & 0.14 & 2.41 & 0.02 & -0.97 & -0.18 & -3.16 & 0.00 \\
\hline Length of Stay & 0.10 & 0.14 & 1.54 & 0.12 & 0.01 & 0.03 & 0.37 & 0.71 & 0.03 & 0.09 & 1.05 & 0.30 \\
\hline Legal status & 0.62 & 0.08 & 1.13 & 0.26 & 1.02 & 0.30 & 4.55 & 0.00 & -1.06 & -0.27 & -4.14 & 0.00 \\
\hline Step 2 & \multicolumn{4}{|c|}{$\begin{array}{l}F(7,305)=6.80, r=.37 \\
r^{2}=.14, \Delta r^{2}=.05, p<0.01\end{array}$} & \multicolumn{4}{|c|}{$\begin{array}{l}F(7,305)=8.54, r=.41, \\
r^{2}=.17, \Delta r^{2}=.03, p<0.01\end{array}$} & \multicolumn{4}{|c|}{$\begin{array}{l}F(7,305)=8.13, r=.40 \\
r^{2}=.16, \Delta r^{2}=.03, p<0.0\end{array}$} \\
\hline $\begin{array}{l}\text { Heritage } \\
\text { Acculturation }\end{array}$ & 0.67 & 0.11 & 1.95 & 0.05 & 0.21 & 0.08 & 1.44 & 0.15 & -0.24 & -0.08 & -1.47 & 0.14 \\
\hline $\begin{array}{l}\text { Host } \\
\text { Acculturation }\end{array}$ & 1.20 & 0.19 & 3.16 & 0.00 & 0.38 & 0.14 & 2.42 & 0.02 & -0.50 & -0.16 & -2.78 & 0.01 \\
\hline
\end{tabular}

\section{Discussion}

This study is, to the best of our knowledge, the first investigating the impact of acculturation on subjective wellbeing among Turkish-American immigrants in the US. Research findings are inconsistent regarding the link between acculturation and immigrants' wellbeing (Berry \& Hou, 2016; Hashemi et al., 2019; Shin \& Lach, 2014). Besides, despite plenty of evidence for the acculturation and wellbeing links in European countries, there is little available research investigating the link between acculturation and subjective wellbeing among Turkish American immigrants (e.g. Carlson \& Güler, 
2018). Thus, the main objective of the present study was to investigate how heritage and host acculturation could predict the subjective wellbeing of Turkish immigrants in the US after controlling sociodemographic variables. The analyses indicated higher involvement in host culture significantly contributed to greater satisfaction with life and positive affect and lessen negative affect beyond the effect of demographic characteristics in tune with other acculturating groups (Jetten et al., 2015; van Oudenhoven \& Benet-Martinez, 2015).

The findings indicated that participants scored high levels of acculturation, satisfaction with life, and positive affect and low levels of negative affect. The overall mean score of heritage and host cultures were relatively high (7.12 and 6.34, respectively) indicating 56.21 percent of Turkish immigrants preferred integration over other acculturation pathways. The results confirmed the acculturation process as not a zero-sum game since heritage culture and host culture were found positively correlated with each other which means preserving heritage cultural domains does not oppose to interact with host society (Bourhis et al., 1997; Carlson \& Güler 2018; Rania et al., 2019; Sommerlad \& Berry, 1970). There may be some explanation regarding this. For instance, Turkish immigrants have enough social capital from both cultural groups to challenge the demands of in host society. Another explanation would be the contextual environment of host American society that supports diversity and laissez-faire integration policy (Bloemraad \& de Graauw, 2012) and higher education attainments and language proficiency of Turkish immigrants (Güler, 2016). Moreover, the literature on Turkish migrants largely focuses on labor migration to Western Europe were not expecting Turkish migrants to have strong relationships with the host society. The finding of the present study is consistent with previous research (Altschiller, 1995; Güler, 2016) indicating that the main reason for migrating to the US was to achieve better living standards followed by educational objectives. Correlation analysis showed that age, socioeconomic status, legal status in the US, length of stay in the US, heritage, and host acculturation were positively significantly correlated with satisfaction with life and positive affect while they were negatively correlated with negative affect. This finding is in tune with previous research showing that participants who migrated at a younger age, had higher socioeconomic status, and resided longer in the host country have greater wellbeing than their counterparts (Balidemaj \& Small, 2018; Grigoryev \& Berry, 2017; Khawaja, Yang, \& Cockshaw, 2016; Rudner \& Orpana, 2012). Even though gender was the most emerging factor in the relationship between acculturation and wellbeing of immigrants, contrary to what was expected, the result of the present study showed no significant gender difference in any variables. This is a very important finding supporting inconsistent results in related research of other demographic groups (Amer \& Hovey, 2007; Balidemaj \& Small, 2018). Besides this finding, there were expections that women would be less likely involved in host cultures that might result in their lesser wellbeing for two reasons. The first was about sex roles in traditional Turkish culture because women were expected to preserve and transmit the culture to the next generations in conjunction with more staying home than working outside, which hinders access to host culture compared to men. The second was that women are more likely to be influenced by family-related situations such as distance from parents which decreases both their wellbeing and involvement with host culture (Güler, 2016). It can be inferred that similar educational attainments and motivation of the immigration decision of participants perhaps influence the present result.

Hierarchical multiple regressions were computed to examine the influence of heritage and host acculturation on satisfaction with life, positive affect, and negative affect. The results of the analysis revealed socioeconomic status in the US and legal status in the US were significant predictors of subjective wellbeing. Testing the unique contribution of heritage and host acculturations to subjective wellbeing beyond the effect of sociodemographic variables led to significant results for the regression model where host acculturation was found to be a unique predictor of cognitive and affective aspects of subjective wellbeing. Regardless of socioeconomic status, having higher levels of host acculturation 
may help to increase immigrants' subjective wellbeing which is a key element of positive human functioning. That is to say, holding American citizenship mitigates immigration-related problems such as negative affect. This is the most important aspect of our paper. Additionally, the result revealed that more involvement in host society was related to greater life satisfaction and wellbeing while least involvements had lowest in which confirming previous research findings (Berry \& Hou, 2016; Dimitrova et al., 2013; Hashemi et al., 2019), indicating social isolation negatively impacting subjective wellbeing.

In early studies, the influence of both heritage and host acculturation on wellbeing have been reported, but the findings have not been conclusive (Berry \& Sabatier, 2010; Güler, 2019; van Oudenhoven \& Benet-Martinez, 2015). Over and above, the previous related studies have been predominantly limited to immigrants in European countries (Abu-Rayya \& Sam, 2017; Dimitrova et al., 2013). This raises the issues of the generalizability of the findings across cultures. It is also inadequate to reflect the variability of cultures around the world in terms of the influence of acculturation on subjective wellbeing. By sampling Turkish American immigrants, our results support the contribution of acculturation, particularly host acculturation, to subjective wellbeing in this understudied sample in the American context. The relationship between acculturation and subjective wellbeing highlighted that contacts with heritage and host cultural groups could bring the best subjective wellbeing (Hashemi et al., 2019; van Oudenhoven \& Benet-Martinez, 2015). However, the model summary from the regression analysis indicated that heritage culture has not accounted for significant variance in the dependent variable. These findings are inconsistent with those of previous studies. These findings may be a result of the characteristics of the sample, more specifically the high educational attainment of participants. This appears to show that more interactions with host culture resulted in better satisfaction with life and higher positive emotions and lessen negative affect. It is expected that immigrants residing in new environments with integrationist aims have protective cultural resources that help to cope with immigration-related problems because of perceiving compatibility between cultures and viewing themselves as part of the in-group.

This study has important implications. Given that there is a scarcity of existing research on Turkish immigrants living in the US, the results of this study have the potential for subsequent research in this area. Researchers should pursue extending available evidence concerning the link between acculturation and subjective wellbeing which can significantly contribute to the theories of acculturation and wellbeing. We found that host acculturation can significantly contribute to the subjective wellbeing of immigrants. Thus, policymakers or practitioners who deal with immigrants may start with creating the necessary conditions where immigrants can find opportunities to contact host cultures which ultimately can influence their wellbeing. Also, policies on immigration implemented by local or national authorities can focus on providing an intergroup climate that can facilitate acculturation orientation accepted by immigrants and members of the host community. This can be done with appropriate measures implemented within public and private organizations. Therefore, it would be possible to foster immigrants' subjective wellbeing by enhancing their contacts with the host culture.

We acknowledged several limitations of this study. First, all study variables were measured using selfreport questionnaires which may have the potential to inflate or deflate the correlation between acculturation, subjective wellbeing, and demographic information. Second, this study used a crosssectional design where it is impossible to infer a causal relationship between acculturation and subjective wellbeing. For example, it is unclear whether acculturation can influence better subjective wellbeing or vice versa. To reach such a conclusion, subsequent research might supplement the current findings with alternative methods, such as experimental or longitudinal designs. Third, although we sampled adults from Turkish-Americans living in the US, the present findings cannot be generalized to 
different Western or non-Western cultures and populations. Future research should examine the extent to which our findings generalize across other groups, such as adolescents and students, whose experiences may vary significantly.

In conclusion, early research has been showing that acculturation has a significant impact on the wellbeing of immigrants, but they are inconclusive and scant on Turkish immigrants in the US. Turkish immigrants in the present study reported higher acculturation to both heritage and American host culture and a greater level of subjective wellbeing. Findings suggest that immigrants with more involvement in host society could have better life satisfaction and emotional wellbeing beyond the effects of demographic characteristics.

\section{Compliance with Ethical Standards}

\section{Ethical Standards}

All study procedures involving human participants followed institutional and/or national research committee ethical standards and the 1964 Helsinki declaration and its later amendments or comparable ethical standards. This study has also been approved by the author's university Institutional Review Board.

\section{Ethical approval}

The study was carried out with the approval of the Office of the Vice President for Research Human Subjects Committee of Florida State University, numbered IRB00000446.

\section{Author Contributions}

The first author developed the concept for this manuscript, carried out the literature search, wrote the manuscript, and proofread it. The second author critically analyzed the data and proofread it. Both authors approved the last version of the manuscript.

\section{Declaration of Conflicting Interests}

The author(s) declared no potential conflicts of interest with respect to the research, authorship, and/or publication of this article.

\section{Funding}

The author(s) received no financial support for the research, authorship, and/or publication of this article.

\section{Data Availability}

The datasets generated during and/or analyzed during the current study are available from the corresponding author on reasonable request.

\section{References}

Abu-Rayya, H., \& Sam, D. L. (2017). Is integration the best way to acculturate? A reexamination of the bicultural-adaptation relationship in the "ICSEY dataset" using the bilineal method. Journal of Cross-Cultural Psychology, 48(3), 287-293. Doi: $10.1177 / 0022022116685846$

Akgün, B. (2000). The Turkish diaspora in the United States and its role in promoting Turkish-American relations. The Turkish Yearbook of International Relations, (31), 99-117. https://dergipark.org.tr/tr/pub/tyir/issue/50036/641467

Alba, R., Reitz, J.G., and Simon, P. (2012). National conceptions of assimilation, integration, and cohesion. In M. Crul \& J. Mollenkopf (Eds.), The changing face of world cities: Young adult children of immigrants in Europe and the United States (pp. 41-61). Russell Sage Foundation.

Altschiller, D. (1995). Turkish Americans. In J. Galens, A. Sheets, \& R. V. Young (Ed.), Gale encyclopedia of multicultural America (pp. 1364-1368). Gale Research.

Amer, M. M., \& Hovey, J. D. (2007). Socio-demographic differences in acculturation and mental health for a sample of 2nd generation/early immigrant Arab Americans. Journal of Immigrant and Minority Health, 9(4), 335-347. Doi: 10.1007/s10903007-9045-y 
Arends-Tóth, J., \& van de Vijver, F. J. R. (2007). Acculturation attitudes: A comparison of measurement methods. Journal of Applied Social Psychology, 7, 1462-1488. Doi: 10.1111/j.1559-1816.2007.00222.x

Balidemaj, A., \& Small, M. (2018). Acculturation, ethnic identity, and psychological wellbeing of Albanian-American immigrants in the United States. International Journal of Culture and Mental Health, 11(4), 712-730. Doi: 10.1080/17542863.2018.1556717

Barsade, S. G., \& Gibson, D. E. (2007). Why does affect matter in organizations? The Academy of Management Perspectives, 21(1), 36-59. Doi: 10.5465/amp.2007.24286163

Berry, J. W. (1997). Immigration, acculturation, and adaptation. Applied Psychology, 46(1), 5-68. Doi: 10.1111/j.14640597.1997.tb01087.x

Berry, J. W. (2005). Acculturation: Living successfully in two cultures. International Journal of Intercultural Relations, 29(6), 697-712. Doi: 10.1016/j.ijintrel.2005.07.013

Berry, J. W. (2019). Acculturation: A personal journey across cultures. In C. M. Allwood (ed.), Elements in psychology and culture series. Cambridge University Press. Doi: 10.1017/9781108589666

Berry, J. W., \& Hou, F. (2016). Immigrant acculturation and wellbeing in Canada. Canadian Psychology/Psychologie Canadienne, 57(4), 254-264. Doi: 10.1037/cap0000064

Berry, J. W., \& Hou, F. (2017). Acculturation, discrimination, and wellbeing among the second generation of immigrants in Canada. International Journal of Intercultural Relations, 61, 29-39. Doi: 10.1016/j.ijintrel.2017.08.003

Berry, J. W., \& Sabatier, C. (2010). Acculturation, discrimination, and adaptation among second-generation immigrant youth in Montréal and Paris. International Journal of Intercultural Relations, 34(3), 191-207. Doi: 10.1016/j.ijintrel.2009.11.007

Berry, J. W., Phinney, J. S., Sam, D. L., \& Vedder, P. (2006). Immigrant youth: Acculturation, identity, and adaptation. Applied Psychology and International Review, 55(3), 303-332. Doi: 10.1111/j.1464-0597.2006.00256.x

Bloemraad, Irene, \& de Graauw. Els. (2012). Immigrant integration and policy in the United States: A loosely stitched patchwork. In James Frideres \& John Biles (Eds.), International perspectives: integration and inclusion (pp. 205-232). Queen's Studies Series, McGill-Queen's University Press. https://escholarship.org/uc/item/2nc0m8bm

Bourhis, R. Y., Moïse, L. C., Perreault, S., \& Senécal, S. (1997). Towards an interactive acculturation model: A social psychological approach. International Journal of Psychology, 32(6), 369-386. Doi: 10.1080/002075997400629

Carlson, E., \& Güler, A. (2018). Cultural involvement and preference in immigrant acculturation. Journal of International Migration and Integration, 19(3), 625-647. Doi: 10.1007/s12134-018-0554-4

Cheung, G. W., \& Rensvold, R. B. (2002). Evaluating goodness-of-fit indexes for testing measurement invariance. Structural Equation Modeling, 9(2), 233-255. Doi: 10.1207/S15328007SEM0902_5

Diener, E. (1984). Subjective wellbeing. Psychological Bulletin, 95(3), 542-575. Doi: 10.1037/0033-2909.95.3.542

Diener, E., Oishi, S., \& Lucas, R. E. (2002). Subjective wellbeing: The science of happiness and life satisfaction. In C.R. Snyder \& S.J. Lopez (Ed.), Handbook of positive psychology. Oxford University Press. https://doi.org/10.1037/0003066X.55.1.34

Diener, E., Pressman, S. D., Hunter, J., \& Delgadillo-Chase, D. (2017). If, why, and when subjective well-being influences health and future needed research. Applied Psychology: Health and Well-Being, 9(2), 133-167. Doi: 10.1111/aphw.12090

Diener, Ed, Robert A. Emmons, Randy J. L., \& Sharon Griffin. (1985). The Satisfaction with Life Scale. Journal of Personality Assessment, 49(1),71-75. Doi: 10.1207/s15327752jpa4901_13

Dimitrova, R., Bender, M., Chasiotis, A., \& van, d. V. (2013). Ethnic identity and acculturation of Turkish-Bulgarian adolescents. International Journal of Intercultural Relations, 37(1), 1-10. Doi: 10.1016/j.ijintrel.2012.04.005

Erdfelder, E., Faul, F., \& Buchner, A. (1996). GPOWER: A general power analysis program. Behaviour Research Methods, Instruments, \& Computers, 28(1), 1-11. Doi: 10.3758/BF03203630

Ferguson, G. M., \& Bornstein, M. H. (2012). Remote acculturation: The "Americanization" of Jamaican islanders. International Journal of Behavioral Development, 36(3), 167-177. Doi: 10.1177/0165025412437066

Gezentsvey Lamy, M. A., Ward, C., \& Liu, J. H. (2013). Motivation for ethno-cultural continuity. Journal of Cross-Cultural Psychology, 44(7), 1047-1066. Doi: 10.1177/0022022113478657

Gordon, M. M. (1964). Assimilation in American life: The role of race, religion, and national origins. Oxford University Press. 
Güler, A. (2016). The effects of ethnic identity in acculturation and psychological wellbeing among Turkish immigrants in the United States (Doctoral Dissertation, Hacettepe University).

Güler, A. (2019). Acculturation process of Turkish immigrants in the United States. Pamukkale University Journal of Social Sciences Institute, (37), 1-13. Doi: 10.30794/pausbed.543991

Gunasekara, A., Grant, S., \& Rajendran, D. (2019). Years since migration and wellbeing among Indian and Sri Lankan skilled migrants in Australia: Mediating effects of acculturation. International Journal of Intercultural Relations, 70, 42-52. Doi: 10.1016/j.ijintrel.2019.02.006

Halman, T. (1980). Turks. In S. Thernstrom, (ed.), Harvard encyclopedia of American ethnic groups (pp. xxv, 1076). Belknap Press.

Hashemi, N., Marzban, M., Sebar, B., \& Harris, N. (2019). Acculturation and psychological wellbeing among Middle Eastern migrants in Australia: The mediating role of social support and perceived discrimination. International Journal of Intercultural Relations, 72, 45-60. Doi: 10.1016/j.ijintrel.2019.07.002

Hernandez, D. J., Denton, N. A., \& Macartney, S. E. (2007). Family circumstances of children in immigrant families: Looking to the future of America. In J. E. Lansford, K. Deater-Deckard, \& M. H. Bornstein (Ed.), Immigrant families in contemporary society (pp. 9-29). Guilford Press.

Jetten, J., Branscombe, N. R., Haslam, S. A., Haslam, C., Cruwys, T., Jones, J. M., . . Murphy, S. (2015). Having a lot of a good thing: Multiple important group memberships as a source of self-esteem. PloS One, 10(6), 1-29. Doi: 10.1371/journal.pone.0124609

Kaya, I. (2004). Turkish American immigration history and identity formations. The Journal of Muslim Minority Affairs, 24(2), 295-308. Doi: 10.1080/1360200042000296672

Khawaja, N. G., Yang, S., \& Cockshaw, W. (2016). Taiwanese migrants in Australia: An investigation of their acculturation and wellbeing. Journal of Pacific Rim Psychology, 10, 1-10. Doi: 10.1017/prp.2016.1

Kwak, K. (2018). Age and gender variations in healthy immigrant effect: A population study of immigrant wellbeing in Canada. Journal of International Migration and Integration, 19, 413-437. Doi: 10.1007/s12134-018-0546-4

Lucas, R. E., \& Diener, E. (2015). Personality and subjective wellbeing: Current issues and controversies. In M. Mikulincer, P. R. Shaver, M. L. Cooper, \& R. J. Larsen (Eds.), APA handbook of personality and social psychology. Vol. 4. (pp. 577-599). APA.

Migration Policy Institute. (2019). U.S. Immigrant population and share over time, 1850-Present. Retrieved from https://www.migrationpolicy.org/programs/data-hub/charts/immigrant-population-over-time.

Nguyen, A. D., \& Benet-Martínez, V. (2013). Biculturalism and adjustment: A meta-analysis. Journal of Cross-Cultural Psychology, 44(1), 122-159. Doi: 10.1177/0022022111435097

Nikolaev, B., Boudreaux, C. J., \& Wood, M. (2019). Entrepreneurship and subjective wellbeing: The mediating role of psychological functioning. Entrepreneurship Theory and Practice, 44(3), 557-586. Doi: 10.1177/1042258719830314

Obasi, E. M., \& Leong, F. T. L. (2009). Psychological distress, acculturation, and mental health-seeking attitudes among people of African descent in the United States: A preliminary investigation. Journal of Counseling Psychology, 56(2), 227238. Doi: $10.1037 / \mathrm{a} 0014865$

Pew Research Center. (2019). Facts on U.S. Immigrants, 2017. Retrieved from https://www.pewresearch.org/hispanic/2019/06/03/facts-on-u-s-immigrants/.

Population Division of the United Nations, Department of Economic and Social Affairs. (2019). International Migrant Stock 2019. Retrieved from https://www.un.org/en/development/desa/population/migration/data/estimates2/estimates19.asp.

Rania, N., Rebora, S., Migliorini, L., \& Navas, M. S. (2019). Acculturation process and life domains: Different perceptions of native and immigrant adults in Italy. The Open Psychology Journal, 12, 55-65. Doi: 10.2174/1874350101912010055

Rudner, A. T., \& Orpana, H. (2012). The health status and health behaviors of immigrant and non-immigrant seniors. The CERIS Working Papers, 88(90), 55-77.

Ryder, A. G., Alden, L. E., \& Paulhus, D. L. (2000). Is acculturation unidimensional or bidimensional? A head-to-head comparison in the prediction of personality, self-identity, and adjustment. Journal of Personality and Social Psychology, 79(1), 49-65. Doi: 10.1037/0022-3514.79.1.49 
Sam, D. L., Vedder, P., Ward, C., \& Horenczyk, G. (2006). Psychological and sociocultural adaptation of immigrant youth. In J.W. Berry, J.S. Phinney, D.L. Sam, \& P. Vedder (Eds.), Migrant youth in cultural transition: Acculturation, identity, and adaptation across national contexts (pp. 117-142). Lawrence Erlbaum.

Schwartz, S. J., Unger, J. B., Zamboanga, B. L., \& Szapocznik, J. (2010). Rethinking the concept of acculturation: Implications for theory and research. American Psychologist, 65, 237-251. Doi: 10.1037/a0019330

Shin, Cha-Nam \& Helen W. Lach. (2014). Acculturation and health of Korean American adults. Journal of Transcultural Nursing, 25(3), 273-280. Doi: 10.1177/1043659614523454

Sommerlad, E. A., \& Berry, J. W. (1970). The role of ethnic identification in distinguishing between attitudes towards assimilation and integration of a minority racial group. Human Relations, 23(1), 23-29. Doi: 10.1177/001872677002300103

Szapocznik, J., Kurtines, W. M., \& Fernandez, T. (1980). Bicultural involvement and adjustment in Hispano-American youths. International Journal of Intercultural Relations, 4(3-4), 353-365. Doi: 10.1016/0147-1767(80)90010-3

Thompson, E. R. (2007). Development and validation of an internationally reliable short-form of the positive and negative affect schedule (PANAS). Journal of Cross-Cultural Psychology, 38(2), 227-242. Doi: 10.1177/0022022106297301

Tip, L. K., González, R., Brown, R., De Tezanos-Pinto, P., Saavedra, P., Sagredo, V., ... Celeste, L. (2015). Effects of ingroup norms on domain-specific acculturation preferences: Experimental evidence from two cultural contexts. International Journal of Intercultural Relations, 47, 113-130. Doi: 10.1016/j.ijintrel.2015.03.027

United States Census Bureau. (2018). Selected population profile in the United States. Retrieved from https://data.census.gov/cedsci/table?tid=ACSSPP1Y2018.S0201\&hidePreview=true \&moe=true

Ünver, Ö., \& Nicaise, I. (2019). Interactive acculturation of Turkish-Belgian parents and children in Flanders: A case study of Beringen. Migration Letters, 16(3), 417-428. Doi: 10.33182/ml.v16i3.601

Van de Vijver, F., Berry, J. W., \& Celenk, O. (2016). Assessment of acculturation. In D. L. Sam \& J. W. Berry (Eds.). Cambridge handbook of acculturation psychology (pp. 93-114). Cambridge University Press.

Van Oudenhoven, J. P., \& Benet-Martínez, V. (2015). In search of a cultural home: From acculturation to frame-switching and intercultural competencies. International Journal of Intercultural Relations, 46, 47-54. Doi: 10.1016/j.ijintrel.2015.03.022

Watson, D., L. A. Clark \& Tellegen, A. (1988). Development and validation of brief measures of positive and negative affect: The PANAS scales. Journal of Personality and Social Psychology, 54(6), 1063-1070. Doi: 10.1037/0022-3514.54.6.1063

West S. G., Finch J. F., \& Curran P. J. (1995). Structural equation models with non-normal variables: Problems and remedies. In: Hoyle R. H. (Ed.). Structural equation modeling: Concepts, issues, and applications. (pp. 56-75). Sage.

Yildirim, M., \& Belen, H. (2018). Fear of happiness predicts subjective and psychological wellbeing above the Behavioral Inhibition System (BIS) and Behavioral Activation System (BAS) model of personality. Journal of Positive Psychology and Wellbeing, 2(1), 92-111. https://journalppw.com/index.php/JPPW/article/view/48 